\title{
KETIDAKSADARAN GABRIEL POSSENTI SINDHUNATA DALAM NOVEL MENYUSU CELENG 2019: SUATU TINJAUAN PSIKOLOGI SASTRA
}

\author{
Sita Dea Krismadana \\ Universitas Sebelas Maret \\ sita_dea@student.uns.ac.id
}

\begin{abstract}
Abstrak
Penelitian ini mengkaji ketidaksadaran pengarang dengan mengambil objek kajian yaitu sebuah novel Menyusu Celeng 2019 karya Gabriel Possenti Sindhunata dengan menggunakan teori psikoanalisis Sigmund Freud. Permasalahan yang dibahas dalam penelitian ini adalah mengenai ketidaksadaran pengarang yang terbentuk melalui kondensasi, pengalihan, dan simbolisasi yang terdapat dalam novel Menyusu Celeng 2019. Pembatasan masalah pada penelitian ini terletak pada bahasa dalam novel Menyusu Celeng 2019 yang merepresentasikan bentuk hasrat dan kejiwaan pengarang. Penelitian ini menggunakan metode penelitian kualitatif dalam bentuk deskripsi interpretasi data dengan data dan sumber. Data diambil melalui karya sastra tersebut dan biografi pengarang yang terdapat pada artikel maupun melalui wawancara dengan pengarang. Simpulan yang dapat diambil dari penelitian ini adalah melalui bahasa metafora dan metonimi yang tertulis, yaitu dengan bentuk kondensasi, pengalihan, dan simbolisasi yang terdapat dalam novel Menyusu Celeng 2019. Melalui bentuk-bentuk tersebut, terdapat hasrat-hasrat terpendam pengarang yang memiliki ketertarikan kepada budaya, keberpihakannya kepada kaum miskin, dan bagaimana pengarang menggambarkan sifat buruk dari petinggi atau pemerintahan.
\end{abstract}

Kata-kata kunci: psikoanalisis, mekanisme mimpi, Sindhunata, Sigmund Freud

\begin{abstract}
This study examines the unconsciousness of the author by taking the object of study, namely the novel Menyusu Celeng 2019 by Gabriel Possenti Sindhunata using Sigmund Freud's psychoanalytic theory. The problem discussed in this research is about the unconsciousness of the author which is formed through condensation, diversion, and symbolization contained in the 2019 Menyusu Celeng novel. This study uses qualitative research methods in the form of data interpretation interpretations with data and data sources taken through the literary work and the author's biography contained in the article or through interviews with the author. The conclusions that can be drawn from this study are through the language of metaphor and written metonymy, namely the form of condensation, diversion, and symbolization contained in the novel Menyusu Celeng 2019. Through these forms there are hidden desires of authors who have an interest in culture, their alignments. to the poor, and how the author describes the bad nature of the higher ups or the government.
\end{abstract}

Keywords: psychoanalysis, dream mechanism, Sindhunata, Sigmund Freud

\section{PENDAHULUAN}

Dalam sebuah karya sastra, imajinasi terwujud melalui kondisi psikologis dan unsur ketidaksadaran pengarang. Kondisi psikologis dan unsur 
ketidaksadaran pengarang memiliki pengaruh yang besar pada ciri karya sastra terutama pada bahasa. Ketidaksadaran mempengaruhi proses kreatif seseorang menciptakan sebuah karya sastra. Pengarang memiliki peran penting dalam psikoanalisis guna meneliti kehidupan masa lalu yang nantinya dapat digunakan untuk analisis karya sastra yang diciptakannya.

Psikologi dibuktikan dapat turut berperan penting dalam penganalisisan sebuah karya sastra dengan bekerja dari sudut kejiwaan karya sastra, baik dari unsur pengarang, tokoh, maupun pembacanya (Budiantoro, 2016: 47). Psikoanalisis pada dasarnya memiliki beberapa pengertian, yaitu sebagai praktik psikologis, praktik akademik, dan sebagai teori (Susanto, 2012: 47). Freud menjelaskan bahwa sastra tercipta melalui tekanan masalah di alam bawah sadar yang dimanifestasikan ke dalam bentuk bahasa. Kejadian yang dialami dan mempengaruhi pengarang juga kerap dituangkan dalam karya sastra melalui proses ketidaksadaran atau mimpi.

Freud merupakan pencetus psikoanalisis yang banyak mendalami mimpimimpi seseorang. Freud memang mempelajari suatu fenomena psikis yang normal (Bertens, 2016: 16). Melalui pendekatan interpretasi mimpi Freud, sisi kejiwaan pengarang dapat diteliti melalui tema yang dipilih, karakter tokoh, dan suasana. Interpretasi mimpi yang diambil dalam penelitian ini dibagi menjadi tiga, yaitu kondensasi, pengalihan, dan simbolisasi.

Kondensasi adalah peralihan pikiran yang tersembunyi pada teks yang merupakan manifes dari mimpi yang kerap berlangsung dengan menggabungkan beberapa pikiran tersembunyi dalam satu imaji (Milner, 1992: 27). Pengalihan merupakan pemberian makna pada sebuah unsur mimpi yang tak berarti. Terkadang pengalihan kerap menimbulkan efek tidak logis (Milner, 1992: 86-87). Simbolisasi memiliki arti yaitu analogi dari mimpi yang muncul dalam bentuk simbol tertentu. Simbolisasi juga merupakan pengungkapan tak langsung dalam sebuah karya, identik dengan sebuah ide yang diperlihatkan dengan penanda-penanda.

Dalam novel Menyusu Celeng 2019 karya Sindhunata, dapat ditemukan bentuk interpretasi mimpi, yaitu kondensasi, pengalihan, dan simbolisasi. Bentuk kondensasi yang muncul dalam novel tersebut adalah metafora pengarang tentang pengalaman dan pandangannya terhadap hidup dengan mengartikan sebuah lukisan, sebagai contoh dalam lukisan pada novel Menyusu Celeng 2019 yang berjudul "Keretaku Tak Berhenti Lama" atau "Ibu yang Tergusur". Kondensasi yang terdapat pada novel Menyusu Celeng 2019 juga digambarkan dengan kebudayaan yang merupakan hasrat tersembunyi Sindhunata yang muncul sejak kecil pengaruh lingkungan tempat tinggal Sindhunata yang lekat dengan kebudayaan. 
Bentuk pengalihan yang muncul yaitu bagaimana Sindhunata menggambarkan sebuah superioritas, sedangkan simbolisasi yang ada dalam novel Menyusu Celeng 2019 adalah suatu simbol celeng yang menggambarkan bentuk keserakahan dan penggambaran eksistensi dengan sebuah panggung politik. Ketiga proses dalam penelitian ini dapat membentuk pekerjaan mimpi dan menyamarkan hasrat yang tidak terwujud dalam keadaan sadar. Ketiga proses tersebut dapat diasumsikan bahwa secara tidak sadar Sindhunata telah memasukkan unsur pribadinya dalam karya sastra meski tidak meleburkan dirinya sebagai objek karya sastra tersebut.

Sindhunata ialah penulis yang juga merupakan redaktur majalah kebudayaan BASIS, wartawan harian Kompas, dan juga menulis banyak karya sastra yang salah satunya digunakan dalam penelitian ini yaitu novel Menyusu Celeng 2019. Novel Menyusu Celeng 2019 merupakan novel politis yang juga membahas tentang keserakahan manusia seperti ketamakan, dengki, korupsi, kemaruk yang digambarkan pada seekor celeng.

Novel Menyusu Celeng 2019 menceritakan kisah pelukis, yaitu Djoko Pekik pada tahun 1965, keadaan zaman orde baru, hingga korupsi e-ktp. Novel Menyusu Celeng 2019 juga membahas tentang kehidupan rakyat kecil yang dengan kesederhaannya dapat menemukan kebahagiaan melalui pekerjaan dan hiburan-hiburan pada pertunjukan budaya, seperti pentas ketoprak, wayang, dan ludruk yang diceritakan.

Novel Menyusu Celeng 2019 merupakan potret perjalanan hidup Sindhunata yang berisi banyak tentang kehidupan masa lalu yang berasal dari lingkungan sederhana dengan kebudayaan yang kental. Kehidupan Sindhunata tersebut didukung saat menjadi seorang wartawan Kompas yang memang mengharuskan Sindhunata terjun langsung pada kehidupan rakyat kecil. Dalam novel Menyusu Celeng 2019, Sindhunata terinspirasi oleh rekan budayawannya, yaitu Djoko Pekik yang ditangkap karena dianggap masuk ke dalam ormas yang tidak sesuai dengan pemerintah dan dirasa lukisannya mengandung unsur anti kolonialisme. Dengan demikian, penelitian ini menganggap novel Menyusu Celeng 2019 cukup menarik untuk diteliti dan dari sudut psikologi sastra, novel ini diyakini oleh peneliti mampu untuk mewakili ketidaksadaran pengarang.

\section{METODE PENELITIAN}

Metode penelitian ini mengambil jenis penelitian kualitatif yang bertujuan untuk memahami fenomena yang dialami subjek penelitian seperti perilaku, persepsi dengan cara deskripsi dalam bentuk kata-kata dan bahasa dan memanfaatkan berbagai metode ilmiah (Moleong, 2012: 6). Objek penelitian ini 
terdiri tadi objek material dan objek formal. Objek material dalam penelitian ini berupa novel Menyusu Celeng 2019 karya Sindhunata. Objek formal penelitian ini berupa ketidaksadaran Sindhunata yang direpresentasikan pada novel Menyusu Celeng 2019 melalui bahasanya.

Sumber data pada penelitian ini adalah novel Menyusu Celeng 2019 karya Sindhunata dan sumber data sekunder pada penelitian ini ialah biografi Sindhunata yang termuat dalam artikel di laman. Selain itu juga melalui artikel yang terkait dengan topik. Data dalam penelitian ini juga dibedakan menjadi data primer dan sekunder. Data primer dalam penelitian ini ialah bahasa yang terdapat dalam novel Menyusu Celeng 2019 karya Sindhunata. Data sekunder dari penelitian ini adalah biografi Sindhunata dan isi novel Menyusu Celeng 2019 karya Sindhunata.

Teknik pengumpulan data dalam proses analisis menggunakan dua teknik penelitian, yaitu pengumpulan data melalui studi pustaka untuk mempelajari sumber yang terkait dengan objek penelitian dengan membaca ulang novel Menyusu Celeng 2019 dan teknik wawancara dengan melakukan analisis melalui hasil wawancara dengan pengarang, yaitu Sindhunata. Teknik analisis data pada penelitian ini dengan berdasarkan pada data yang terkumpul menggunakan teori psikoanalisis Sigmund Freud. Penelitian ini membagi data yang kemudian diinterpretasikannya. Interpretasi data merupakan ekspresi gejala kejiwaan dan kepribadian pengarang.

\section{ANALISIS DAN PEMBAHASAN}

\section{Psikobiografi Gabriel Possenti Sindhunata}

Psikobiografi adalah ulasan mengenai data diri seseorang yang mencakup kehidupan masa lalunya. Dengan mempelajari psikobiografi seseorang, peneliti dapat memahami kondisi kejiwaan pengarang. Kajian psikologi pengarang berhubungan dengan aspek kejiwaan pengarang yang meliputi tentang penciptaan karya sastra, pengalaman individual dan lingkungan pengarang, serta tujuan khusus yang berpengaruh terhadap penciptaan karya sastra (Wiyatmi, 2011: 33). Dalam memahami kejiwaan seseorang, peneliti dapat memahami karya-karya yang dihasilkannya.

Sindhunata yang memiliki nama lengkap Gabriel Possenti Sindhunata juga dikenal dengan panggilannya yaitu Romo Sindhu karena ia merupakan seorang imam Katholik. Sindhunata lahir di kota Batu, Jawa Timur pada 12 Mei 1952. Selain menjadi seorang imam, Sindhunata juga merupakan seorang sastrawan, wartawan, redaktur, budayawan, dan pakar filsafat. Sindhunata menjadi 
pemimpin redaksi majalah Basis, majalah Utusan menjadi wartawan Kompas yang juga dikenal karena komentarnya mengenai sepak bola, dan juga menjadi kurator di Bentara Budaya Yogyakarta.

Sindhunata memang terkenal dengan kecintaannya pada rakyat kecil. Hal tersebut diawali karena tempat tinggalnya yang berada di lingkungan yang sederhana. Menurut Sindhunata (Jumat, 15 Mei 2020), “Saya kira lingkungan saya sendiri bukan berada tapi biasa, teman-teman saya juga orang kampung sehingga saya tidak asing dengan semuanya. Saat saya di Pakem juga kerja di gereja desa. Jadi, dari dulu saya memang begitu. Saat di Kompas juga keliling di sudut kota ketemu orang-orang pedagang asongan. Jadi, tidak satu dua orang saja. Jadi, misalnya saya bertemu dengan Pak Amin tukang cat, tapi dia punya ilmu kebatinan yang dalam. Saya kenal orang kecil, tapi mistiknya kuat sekali. Ketemu di jalan Mbah Sastro penjual arang yang jualan jam 3 pagi lalu saya ikuti saya wawancara ternyata hidupnya dalam sekali, jadi membuat saya hiburan tersendiri. Orang kecil jangan dikira miskin, dalam sekali mereka," ungkap Sindhunata.

Tak hanya lingkungan tempat tinggalnya yang mendukung Sindhunata pro dengan rakyat kecil, namun karena pekerjaannya sebagai wartawan Kompas membuat Sindhunata lebih terjun kepada kesederhanaan "Tak terbayangkan oleh kita mau membuat reportase dan menulis sepertinya. Dia mengisahkan percintaan dua orang gelandangan, penggembala kambing yang cacat, pengayuh perahu penyeberangan di tepi kali Bekasi. Wanita yang sedang mengandung dan terancam banjir di Pluit. Karsi si anak Mini, cerita rasa cemburu dan cinta di antara PSK di Kramat Tunggak dan lainnya. Juga proses kelahiran ikan pesut di Ancol. Pendeknya, dia mereportase dan menulis topik dan figur yang tak terperhatikan oleh kita wartawan ibu kota umumnya" (Dimas Supriyanto, https://trenzindonesia.com/2020/01/12/sindhunata-bukan-kita/).

Sindhunata melewati dunia pendidikan yang cukup panjang. Sindhunata menyelesaikan pendidikannya dari Seminarium Marianum, Lawang, Malang pada tahun 1970. Pada tahun 1980, ia menyelesaikan studi sarjana filsafat di Sekolah Tinggi Filsafat Driyarkara, Jakarta. Pada tahun 1983, Sindhunata menyelesaikan studi teologi di Institut Filsafat Teologi Kentungan Yogyakarta pada tahun 1983. Di tahun 1986 hingga 1992, Sindhunata juga melanjutkan studi doctoral filsafat di Hochschule Fur Philosophie, Philosophische Fakultat SJ di Munchen, Jerman. Sejak duduk di bangku sekolah menengah, Sindhunata sudah gemar membaca buku-buku bergenre budaya, sejarah, filsafat, atau bahkan novel dan puisi. Hal tersebut dibuktikan saat sekarang Sindhunata telah menerbitkan banyak karya sastra dan bagaimana tulisannya kerap berisi tentang kebudayaan. 
Kebudayaan ini mengarah kepada kehidupan Sindhunata yang muncul sejak masa kanak-kanak. Sejak kecil, Sindhunata akrab dengan kebudayaan dengan kerap menonton kesenian-kesenian rakyat. Melalui kebiasaannya tersebut, Sindhunata pun kenal dengan pemain dalam pentas tersebut maupun orang-orang di belakang layar. Menurut Sindhunata (Jumat, 15 Mei 2020) "Karena tadi saya dekat dengan realitas orang kecil dan dekat dengan budayanya, saya juga mau tidak mau ya dekat. Novel Anak Bajang Menggiring Angin saya juga menceritakan wayang. Saya dibesarkan dengan kultur Jawa dan saya akrab sekali dengan budaya dan saya juga pelaku. Saya sebenarnya tidak suka disebut budayawan, saya hanya pelaku yang memiliki arti dapat merasakan apa itu budaya Jawa, dengan negatif atau positifnya," ujar Sindhunata.

Buku-buku yang diterbitkannyapun bermacam seperti buku-buku ilmiah, yaitu Dilema Usaha Manusia Rasional, Hoffen auf den Ratu Adil-Das eschatologische Motiv des "Gerechten Königs" im Bauernprotest auf Java während des 19 und zu Beginn des 20 Jahrhunderts (Menanti Ratu Adil - Motif Eskatologis dari Ratu Adil dalam Protes Petani di Jawa Abad ke-19 dan awal Abad ke-20) dan Sakitnya Melahirkan Demokrasi (1999). Buku-buku yang ditulis dalam bahasa Jawa adalah Aburing Kupu-kupu Kuning, Ndhérék Sang Déwi ing Éréng-érénging Merapi Redi Merapi, Sumur Kitiran Kencana, dan Nggayuh Gesang Tentrem. Novel terkenalnya adalah Anak Bajang Menggiring Angin. Karya sastranya yang lain adalah Air Penghidupan, Semar Mencari Raga, Mata Air Bulan, Tak Enteni Keplokmu Tanpa Bunga dan Telegram Duka yang pada tahun 2019 ini berganti menjadi Menyusu Celeng, juga buku kumpulan puisinya seperti buku Air Kata-kata.

Sindhunata juga menerbitkan trilogi tentang catatan sepak bolanya, yaitu Air Mata Bola, Bola di Balik Bulan, dan Bola-bola Nasib yang diterbitkan pada tahun 2002. Buku ilmu tertawa yang berangkat dari dagelan ludruk Ilmu Ngglethek Prabu Minohek juga Sindhunata terbitkan pada tahun 2004 dan menulis bukunya filsafat slebor becak berjudul Waton Urip. Tahun 2006, features nya yang terpilih dari Harian Kompas diterbitkan serentak dalam lima buku: Dari pulau Buru ke Venezia, Segelas Beras untuk Berdua, Ekonomi Kerbau Bingung, Petruk Jadi Guru, dan Burung-burung di Bundaran HI. Pada tahun 2007, Sindhunata meluncurkan novel Putri Cina.

Penelitian ini menemukan kerangka pikiran bawah sadar Sindhunata dalam novel Menyusu Celeng 2019. Penelitian ini menggunakan teori psikoanalisis Sigmund Freud untuk meneliti ketidaksadaran pengarang melalui media bahasa. Peneliti menetapkan sebuah novel karyanya, yaitu Menyusu Celeng 2019 yang diterbitkan dengan judul barunya tersebut pada tahun 2019. Novel tersebut dipilih karena diterbitkan dengan judul yang sangat simbolik dan 
karena awal tahun diterbitkannya dianggap mampu mewakili salah satu periode penting dalam karier Sindhunata.

\section{Bingkai Ketidaksadaran}

Sastra secara langsung menampilkan ketidaksadaran bahasa. Ketidaksadaran yang dimaksud adalah alam bawah sadar pengarang dalam sebuah penciptaan karya sastranya (Ratna, 2004: 350). Tujuan memahami psikologi sastra ialah untuk memahami aspek-aspek kejiwaan yang terkandung dalam karya sastra (Endraswara, 2008: 11). Psikologi sastra memiliki daya tarik tersendiri, yaitu pada masalah manusia yang melukiskan potret jiwa, tak hanya jiwa sendiri yang muncul dalam sastra tetapi juga bisa mewakili jiwa orang lain (Minderop, 2016: 59).

Begitu pula dalam novel Menyusu Celeng 2019 yang terinspirasi oleh pelukis terkenal, yaitu Djoko Pekik yang pada tahun 1965 ditahan karena dianggap bergabung dengan PKI dan lukisannya yang dituduh menggambarkan anti kolonialisme. Sindhunata berniat untuk menuliskan sebuah novel dengan lukisan Djoko Pekik, yaitu sebuah celeng. Bagi Sindhunata, celeng menggambarkan sebuah tindakan keserakahan, kejahatan, ketamakan yang kerap ada dalam sifat manusia dengan latar belakang apapun. Selain itu, celeng juga digambarkan karena terkenal sebagai hewan untuk mencari pesugihan.

Sindhunata adalah sosok yang sangat mendukung rakyat kecil dan miskin karena sejak kecil hidup di lingkungan yang sederhana dan kental dengan budaya. Tema tersebut merupakan metafora yang dibentuk untuk menjadi bagian dari dirinya dan tidak dapat lagi dipisahkan. Maka dengan kebiasaannya tersebut, Sindhunata ingin menyuarakan suara rakyat dengan tulisannya, melalui ciri khasnya yang selalu membawa kebudayaan dan menyisipkan bahasa Jawa.

Dan demikian dalang ketoprak itu berucap: Kocap kacarita, kacarita datan kocap. Seje kandhane nunggal caritane. Inggih menika ta warnanira desa peranganing bawana kangaran Ngalengkadiraja. Desa sing katerak garis katulistiwa iku mula desa kang gemah ripah loh jinawi, thukul kang sarwa tinandur nanging larang yen arep tuku (Sindhunata, 2019: 94). Kutipan tersebut memiliki arti dalam bahasa Indonesia, yaitu "Alkisah, dapat diceritakan tak dapat diucapkan. Lain katanya sama ceritanya. Inilah wajah desa sebagai bagian jagad raya, yang dinamai Ngalengkadiraja. Desa yang diterjang garis khatulistiwa itu sesungguhnya adalah desa yang kaya raya subur, apa saja yang ditanam tumbuh tapi mahal bila mau dibeli."

Dalam kutipan tersebut dapat dibuktikan bahwa Sindhunata memang akrab dengan kebudayaan. Sindhunata lahir di sebuah desa yang masih kental 
dengan kebudayaannya yang akhirnya membuatnya jatuh hati pada budaya Jawa. Sindhunata telah mengenal budaya dan bahasa Jawa sejak kecil karena sejak kecil ia kerap menonton pementasan budaya seperti ludruk, ketoprak, dan wayang. Saat kecil, Sindhunata mengaku pernah dimarahi karena menonton wayang semalam suntuk padahal esok hari Sindhunata harus berangkat sekolah. Hal tersebut yang membuat Sindhunata menciptakan karya sastra yang tidak jauh dengan kebudayaan Jawa dan bahasa Jawa yang memang memiliki tujuan untuk menyetarakan bahasa Jawa dengan bahasa Indonesia agar tidak dipandang remeh, terutama untuk anak muda zaman sekarang.

Warga desa sedikit lega karena dalam pemilihan desa, Mbak Tiwung jago mereka, mengatasi Pak Gareng. Mbak Tiwung adalah jago dari kelompok monteng yang menang atas kelompok Dokar yang menjagokan Pak Gareng. Tapi, apakah Mbak Tiwung dapat menjabat sebagai lurah ini masih harus diperjuangkan dalam sidang Dewan Prabot Desa. Kelompok Monteng yakin Dewan Prabot Desa pasti akan mengesahkannya, Warga Desa mengharapkan banyak dari Mbak Tiwung. Namun mereka terpaksa kecewa. Mbak Tiwung ternyata tidak banyak bicara. Ia terlalu diam untuk seorang pemimpin (Sindhunata, 2019: 99).

Dalam kutipan tersebut, Sindhunata menggambarkan pemilu dengan pentas ketoprak yang pemainnya memerankan partai politik dan calon-calon pemimpin yang dianggap celeng. Pentas ketoprak tersebut menggambarkan saat pemilu yang menampilkan calon-calon pemimpin yang hanya "bermain-main" saat pemilihan umum yang semuanya sudah direncanakan. Novel Menyusu Celeng 2019 juga menceritakan kacaunya reformasi, bagaimana setelah itu korupsi tambah melimpah, bahkan agama dijadikan sarana untuk ketamakan tersebut. Dimulai tragedi 1965 atau pergulatan orang-orang yang tergabung pada Lekra, gaya kepemimpinan Soeharto pada zaman Orde Baru, hingga peristiwa politik yang melatarbelakangi reformasi 1997-1998 dan keserakahan politik korupsi e-ktp pun dibahas pada novel ini. Meski tanpa menyebut nama para tokoh yang terlibat dan sering kali menggunakan istilah Jawa, seperti neptu, ramalan Jayabaya, dan istilah pewayangan, pembaca bisa merasakan dan mendapatkan konteks sejarah siapa saja nama-nama yang dimaksud jika mengetahui latar belakangnya

\section{Kondensasi dalam Novel Menyusu Celeng 2019}

Kondensasi adalah peralihan pikiran yang tersembunyi pada teks hasil manifestasi dari mimpi. Kondensasi sering berlangsung melalui penggabungan atau penumpukan beberapa pikiran tak sadar ke dalam hal-hal, seperti tokoh, peristiwa, kata, dan hal bersifat umum lainnya ke dalam satu ide. Mimpi 
merupakan peleburan beberapa tokoh atau hal yang memiliki sifat yang umum ke dalam satu gambar, atau bahkan peleburan beberapa kata yang mengacu kepada realitas yang berbeda dalam satu kata. Menurut Milner, gejala kondensasi memiliki analogi, pertama dengan penciptaan tokoh-tokoh sandiwara atau penulis roman (1992: 43). Dalam novel Menyusu Celeng 2019, peneliti akan menggambarkan bentuk kondensasi sebagai wujud kejiwaan atau pemikiran Sindhunata.

Novel Menyusu Celeng 2019 terdapat sebuah wujud kesederhanaan yang diceritakan dalam bentuk lukisan pada bagian pertama novel tersebut. Kesederhanaan tersebut memberikan cerminan kejiwaan masa lalu Sindhunata yang memang hidup dalam lingkungan yang sederhana. Tak hanya masa kecilnya yang mampu mencerminkan kejiwaan, namun hal tersebut juga diperlihatkan saat Sindhunata menjadi seorang wartawan Kompas sejak tahun 1977 yang mengharuskan Sindhunata terjun ke dalam kehidupan rakyat kecil untuk memahami kesederhanaan secara lebih nyata. Menurutnya, hidup wartawan bukan hanya berada di kantor melainkan sepenuhnya di jalanan.

Sindhunata melalui tindakan tersebut menjadi semakin mengenal banyak orang-orang kecil dengan kesederhanaan hidupnya. Kesederhanaan memberikan gambaran akan kejadian yang dialami oleh beberapa orang dalam realitasnya dan kejadian tersebut pun akhirnya menjadi objek atau bahan bagi sebuah penulisan karya sastra seperti novel atau kumpulan puisi miliknya.

Memang setiap sore di rel pinggir jalan yang disebutkannya lewat kereta panjang yang mengangkut manusia-manusia yang pulang dari kota. Manusia-manusia itu umumnya adalah buruh, pekerja kasar, rakyat jelata, dan orang-orang miskin. Mereka memenuhi kereta, berjubel di gang-gang dan sambungan-sambungan gerbong, bahkan sampai naik ke atap-atapnya (Sindhunata, 2019: 24).

Melalui penggalan tersebut, penelitian ini membuktikan bentuk represi kesederhanaan bagi Sindhunata dijelaskan melalui penggambaran lukisan dalam novel tersebut. Lukisan pertama yang berjudul "Keretaku Tak Berhenti Lama" menceritakan beban kehidupan masyarakat yang berdesak-desakan untuk pulang ke rumah setelah bekerja sebagai buruh. Kereta yang sudah penuh sesak dengan kerumunan orang tidak memadamkan niat orang yang sudah berada di dalam untuk memperbolehkan orang lain masuk yang membuktikan bahwa pekerja-pekerja tersebut tetap dapat memberikan perhatian dan pertolongan pada sesamanya meski mereka juga dalam keterbatasan.

Penggambaran kesederhanaan Sindhunata yang turut dituangkan dalam karya sastranya secara tidak sadar melalui lukisan. Lukisan tersebut membuat 
Sindhunata menggambarkan kehidupan sederhana dari para buruh, bagaimana transportasi umum merupakan hal yang selalu dinantikan karena para pekerja yang pada saat itu tidak memiliki kendaraan pribadi. Sifat sosial yang digambarkan dalam lukisan tersebut saat seorang mau masuk dalam gerbong kereta masih dipersilakan oleh orang-orang di dalam, meski kenyataannya kereta tersebut sudah penuh sesak oleh orang-orang yang sudah berada di dalam kereta. Kesederhanaan Sindhunata memang kerap dimasukkan dalam setiap karya sastranya.

\author{
Adhuh Dik aku 'rakleru \\ aja dadi atimu \\ tak arani celeng sliramu \\ susur celeng disosor meri \\ aku nyleweng mohon di sorry (Sindhunata, 2019: 141).
}

yang memiliki arti “Aduh Dik aku tak keliru

Jangan jadi hatimu

Kupanggil celeng dirimu

Susur celeng disosor meri

Aku nyleweng mohon di sorry"

Dalam kutipan tersebut menggunakan bahasa Jawa yang membuktikan kebudayaan Jawa yang ingin dilestarikan oleh Sindhunata karena ia memang dilahirkan dari lingkungan yang kental dengan budaya. Kutipan tersebut menceritakan budaya Jawa yang juga terkenal dengan lagu cinta "Ojo Sembrono" yang diubah menjadi lagu cinta celeng yang dalam novel Menyusu Celeng 2019 menceritakan saat semua orang menonton pertunjukan daerah, tibatiba semua penonton berubah menjadi celeng dan bernyanyi menari dengan berbagai lagu celeng yang tentunya dilagukan dengan bahasa Jawa.

Menurut Sindhunata, untuk menyindir seseorang akan lebih "ngena" jika menggunakan bahasa Jawa, entah dalam senggakan, pantun, puisi, dan sebagainya. Sindhunata menganggap di masa sekarang ini sedikit orang yang dapat berbincang maupun menulis menggunakan bahasa Jawa. Dalam ketekunannya pada penulisan Bahasa Jawa tersebut, Sindhunata tidak peduli jika karyanya tidak dianggap sebagai Sastra Indonesia karena memang menurutnya 
karyanya kerap menjadi perbincangan dalam kalangan penyair dan sastrawan. Sindhunata mengaku bahwa tidak ingin bahasa Jawa dipandang nomor dua dari bahasa Indonesia, jadi dalam proses kreatif nya Sindhunata tidak membedakan bahasa dalam penulisannya.

\section{Pengalihan dalam Novel Menyusu Celeng 2019}

Pengalihan adalah salah satu teknik dalam memahami pengarang. Pengalihan berarti memberikan makna pada sebuah unsur mimpi yang tidak berarti, tetapi akan terlalu menonjol jika digabungkan dengan unsur lain yang tepat. Menurut Freud, pengalihan memiliki arti sebagai mimpi yang menonjolkan sesuatu yang sama sekali tidak berhubungan dengan pikiran laten yang harus segera diwujudkan. Konsep yang sama terjadi dalam puisi dan retorika, yakni metonimi. Metonimi merupakan proses pengungkapan suatu kata dengan kata yang lain dan memiliki makna berdampingan. Contohnya, penyebutan sebagian sebagai ganti keseluruhan (perunggu untuk medali) atau penyebutan waktu sebagai ganti suasana (malam untuk gelap).

Metonimi kenyataan dapat ditemukan dalam novel Menyusu Celeng 2019. Sindhunata ingin mengungkapkan bahwa di dalam dunia ini ada kenyataan yang harus dihadapi dan diakui kebenarannya, entah kebenaran tersebut dirasa buruk atau memalukan. Hal tersebut memiliki hubungan yang sama dengan fungsi agama bagi Freud yang menurutnya, agama merupakan sebuah ilusi yang diartikan sebagai kebenaran.

Lalu hadirin diminta untuk mengucapkan namanya, dan mengaku "aku adalah celeng". Tanpa kecuali, seniman, rohaniwan, wartawan, politikus, wakil rakyat, intelektual, pengusaha, pejabat, mahasiswa, anak-anak sekolah, anak-anak TK, pendek kata semua yang hadir pada malam itu menyebut namanya sendiri-sendiri, dan mengaku dirinya adalah celeng (Sindhunata, 2019: 174).

Kutipan yang terdapat dalam novel Menyusu Celeng 2019 tersebut menceritakan pementasan upacara adat larungan. Diceritakan semua orang diminta untuk mengakui bahwa dirinya adalah seekor celeng. Tak peduli latar belakang penonton disana, entah rohaniwan, politikus, pengusaha, anak-anak, semua orang diperintah untuk mengakui dirinya adalah seekor celeng.

Sindhunata menginginkan semua orang intropeksi dan mengakui keburukan yang ada di dalam dirinya. Potret tersebut, Sindhunata menginginkan pembacanya mengenali hal-hal buruk dan hal-hal baik dalam dirinya tanpa merasa dirinya paling baik. Sesuai dengan penjelasan Freud bahwa akan ada kehidupan setelah mati, dan kehidupan setelah mati tersebut 
tergantung pada kehidupan sebelumnya, bagaimana kita menyadari kejahatan kita yang ada akan berdampak pada kehidupan kita setelah kematian tersebut.

Kebangkitan juga menjadi titik utama yang ditekankan Sindhunata pada setiap hasil karyanya. Sindhunata kerap menampilkan sosok kemiskinan yang nantinya tetap bangkit optimis dalam menjalani kesehariannya. Sindhunata juga merupakan sosok yang gigih dan semangat dan membuktikan sebuah pencapaian hidup yang luar biasa.

"Ia duduk di tepi Kali Bedhog. Arus kali mengalir dengan tenang. Air kelihatan segar dan bening. Diamatinya arus kali itu. Arus itu tetap sama, dirinya yang telah berubah. Dulu ia adalah orang miskin. Setelah ia menjadi pelukis ternama, ia menjadi berpunya. Ia bahkan terhitung kaya raya. Dulu sering ia bermimpi, suatu saat lukisannya akan diminati orang dan laku. Kini impiannya menjadi kenyataan" (Sindhunata, 2019: 54).

Kutipan tersebut menggambarkan kehidupan rakyat kecil yang tidak mudah menyerah karena keadaan yang dihadapinya. Melalui kekurangannya rakyat kecil berani berjuang melawan segala kesusahan. Sindhunata ingin memperlihatkan bahwa banyak orang-orang yang tidak beruntung, namun dengan ketidakberuntungannya mampu bangkit dan hidup bahagia, terutama pada kutipan tersebut yang merupakan penggambaran Djoko Pekik teman seniman yang sejak lama dikenalnya. Sindhunata menggambarkan kehidupan Djoko Pekik yang dahulu memang bekerja sebagai panjahit karena sudah berhenti melukis dan tidak memiliki pekerjaan lain, namun jiwa melukisnya masih ada. Maka dari itu Djoko Pekik dengan semangatnya bangkit untuk menjadi sukses dengan pekerjaan yang ia cintainya, yaitu melukis.

Bagi kelompok seniman lain, kelompok kerakyatan ini dianggap telah menyimpang dari cita-cita seni yang harus berdiri di atas kepentingan dan masalah politik. Karena kedekatannya dengan kelompok politik tertentu, yang rupanya sedang mendapat angina untuk berkuasa, kelompok seni bergaris kerakyatan itu memang sudah merasa menang dan berkuasa pula. Penampilan dan sikap beberapa anggota mereka yang yakin, seni mereka yang berpihak pada perjuangan rakyat itulah seni yang mutlak benar, seni lainnya keliru dan merupakan impian yang menyesatkan belaka. Karena sikap dan pendirian itu, kubu seniman berhaluan lain menganggap mereka sombong. Mereka pun dibenci. Mereka bahkan harus dilawan karena memutlakkan kebenaran seni mereka sendiri (Sindhunata, 2019: 68). 
Metonimi yang terdapat dalam novel Menyusu Celeng 2019 juga digambarkan dalam bentuk superioritas. Superioritas adalah istilah untuk memperlihatkan keunggulan atau kelebihan pribadi. Superioritas pada novel Menyusu Celeng 2019 terdapat pada bagian pelukis yang terinspirasi dari kehidupan Djoko Pekik yang ditangkap oleh polisi karena dianggap menjadi pengikut PKI yang dinggap menyeleweng selain itu juga karena lukisannya dituduh seruan anti kolonialisme.

Menurut wawancara Djoko Pekik dengan Tempo.co tanggal 30 September 2015, secara struktural, Lekra tidak terkait dengan Partai Komunis Indonesia. Memang, sebagian besar seniman Lekra bergabung dengan PKI. Namun, Djoko Pekik merupakan seniman Lekra yang tidak bergabung ke dalam PKI. Selain alasan tersebut, Djoko Pekik ditangkap karena dianggap banyak melukis karyakarya antikapitalisme dan sering mengikuti demonstrasi. Dengan alasan tersebut, Djoko Pekik ditangkap pada tahun 1965. Namun dengan penjelasannya, tidak mengubah kehidupannya, justru Djoko Pekik tetap dipenjarakan.

Hal tersebut didukung kutipan di atas yang menceritakan tentang beberapa kelompok seniman yang dibahas pada novel tersebut. Namun, kelompok seniman tersebut memiliki idealisme yang berbeda. Bagi kelompok seniman lain, kelompok kerakyatan yang diikuti oleh tokoh utama, yaitu si pelukis dianggap menyimpang dari cita-cita seni yang ada, yang harus berdiri di atas kepentingan partai politik. Namun karena sifat sombong yang dirasakan oleh kelompok seniman lain ada pada kelompok si pelukis, mereka dibenci dan dilawan. Hal ini mempertunjukkan superioritas dari kelompok seniman yang merasa dirinya lebih baik dari kelompok yang lain dan lebih benar dari pemikiran kelompok lain.

\section{Simbolisasi pada Novel Menyusu Celeng 2019}

Simbolisasi ialah analogi dari mimpi yang muncul dalam bentuk simbol tertentu. Simbolisasi juga merupakan pengungkapan tak langsung dalam sebuah karya, identik dengan sebuah ide yang diperlihatkan dengan penanda-penanda. Figurasi analogis, dapat disamakan dengan metafora (harus didiskusikan dan diberi nuansa, yaitu mengganti sebuah ujaran dengan penanda lain, bukan dengan penanda terdekat seperti metonimi, tetapi dengan penanda yang mempunyai hubungan kemiripan dengan penanda yang pertama (Milner, 1992: 44). Simbolisasi dapat disamakan dengan metafora dalam puisi, mengganti definisi denotatif ke dalam konotatif. 
Ketamakan merupakan keinginan untuk memperoleh harta secara terus dan sebanyak-banyaknya. Ketamakan yang diperlihatkan dalam novel Menyusu Celeng 2019 ini menyorot tentang pemerintahan yang berperilaku tidak adil yang biasanya dibuktikan dalam bentuk korupsi, serakah, gila kuasa, dan perilaku buruk lainnya. Sindhunata menampilkan sosok ketamakan tersebut dengan menggunakan hewan celeng atau babi hutan yang dianggap merupakan hewan yang sering digunakan untuk pesugihan yang tidak memiliki kepuasan dalam mencari kekayaan. Sosok celeng yang digambarkan memang terinspirasi melalui lukisan Djoko Pekik yang dikembangkan menjadi sebuah novel.

Lembaga-lembaga pemerintahan dan lembaga-lembaga perwakilan rakyat dipenuhi dengan insan-insan celeng. Di lembaga-lembaga itu apa saja bisa dicelengkan. Jabatan diperjualbelikan secara celeng, anggaran dirancang dengan perhitungan celeng, proyek-proyek pembangunan diselewengkan dengan transaksi celeng. Bahkan politik pun diuangkan dengan uang celeng (Sindhunata, 2019: 161).

Simbolisasi ketamakan yang dimunculkan pada novel ini juga mengacu pada judul novel yaitu Menyusu Celeng 2019. Celeng kerap diasumsikan sebagai hewan ketamakan yang serakah, ingin menang sendiri, egois, dan suka menimbun kekayaan. Celeng pada zaman sekarang ini juga digunakan sebagai hewan pesugihan, yaitu babi ngepet yang dengan tindakannya dapat merugikan orang lain, namun dapat meraup untung yang besar dengan cara yang salah.

Kutipan tersebut dengan cukup jelas menggambarkan ketamakan yang dimiliki oleh setiap orang, khususnya pemerintah yang berlaku sewenangwenang. Ketamakan yang ada pada penguasa membuat rakyat-rakyat kecil menderita karena perlakuannya yang semena-mena, tidak adil, korupsi, dan mementingkan diri sendiri dengan penggambaran seekor celeng. Ketamakan yang diceritakan pada kutipan diatas memperlihatkan bahwa semua hal bisa dibeli dengan uang atau dengan jabatan, dan keserakahan tersebut dapat menguasai kekayaan untuk dirinya sendiri, keluarga, ataupun kroni-kroninya. Sindhunata berhasil melewati ketamakan yang dihadapinya dengan mengkritik pemerintah melalui novel yang dibuatnya dengan menyebut mereka melalui sebutan celeng.

Selain ketamakan, novel ini juga menggambarkan metafora eksistensi. Eksistensi yang merupakan wujud pengakuan dan penghargaan. Banyak orang sering mencari eksistensi dalam menceritakan kehebatannya di antara orang lain, dan biasanya eksistensi memang dijumpai pada diri orang-orang yang lebih memiliki derajat tinggi. 
Pak Gareng, lurah baru Desa Ngalengkadiraja menggantikan Prabu Celeng Dhegleng, berjanji memenuhi tuntutan rakyat. Ternyata ia terus mengulur-ulur janjinya saja. Rakyat desa jadi meragukan kemampuannya. Menurut mereka, Pak Gareng memang tidak pantas jadi lurah (Sindhunata, 2019: 98-99).

Menurut Sindhunata, eksistensi pada novel ini digambarkan dengan pentas ketoprak yang memang diibaratkan sebagai sebuah panggung politik pencalonan presiden. Diceritakan dalam novel Menyusu Celeng 2019, terdapat seorang lurah yang terus berjanji untuk memenuhi tuntutan rakyat, namun nyatanya hanya janji palsu yang terus diucapkannya. Begitu pula Sindhunata memandang pemerintahan yang memang kerap berjanji saat pencalonan, dan lupa akan segala janjinya saat sudah menjabat. Hal tersebut dituliskan Sindhunata untuk mengkritik pemerintahan dengan cara yang seabstrak mungkin.

Ada saja alasan yang direkayasa. Sehari hari ia sehat walafiat namun ketika mau diperiksa, tiba-tiba gula darahnya naik. Lalu, ketika mau menyerahkan diri, mobilnya menabrak tiang listrik. Ia tidak jadi masuk tahanan, tapi masuk rumah sakit. Pihak rumah sakit pun bisa diajak kompromi untuk menunda dia dibui (Sindhunata, 2019: 163).

Penggambaran dalam kutipan tersebut menceritakan bagaimana seorang koruptor yang menggunakan segala usahanya untuk menghindari penangkapan polisi yang didukung oleh banyak pihak. Segala drama dilakukannya, seperti gula darah naik, menabrak tiang listrik demi menundanya dibui. Sindhunata juga menyimbolkan sebuah eksistensi dengan gambaran panggung sandiwara yang terus dibuatnya yaitu seorang koruptor yang terkenal dengan segala sandiwaranya. Dengan mudah menyuap siapa saja agar mendukung dan menutup mulut atas semua sandiwaranya, kesalahannya sudah cukup kuat dibuatnya sendiri, namun karena kekuasaannya dan kekayaan yang dimilikinya, ia mampu menutup mulut orang-orang disekitarnya untuk membantu menunda dijebloskannya ia dalam penjara.

Berdasarkan psikobiografi dan mekanisme mimpi yang terdapat dalam novel Menyusu Celeng 2019 yang terdiri dari kondensasi, pengalihan, dan simbolisasi dapat dibuktikan bahwa novel Menyusu Celeng 2019 dilahirkan Sindhunata untuk memenuhi ketidaksadarannya dalam keberpihakannya kepada kaum miskin dan kecintaannya kepada budaya yang memang sudah ada di lingkungan tempat tinggal Sindhunata sejak kecil. Sindhunata mencerminkan keberpihakannya terhadap rakyat kecil melalui metafora dan metonimi kesederhanaan, kebudayaan, kenyataan, dan kebangkitan juga untuk menguatkan semangat rakyat kecil yang hidup di sekitarnya. Dalam novel Menyusu Celeng 
2019, Sindhunata juga ingin menyuarakan haknya untuk protes kepada sikap pemerintahan yang dianggap celeng, yaitu sifat buruk yang sering diperlihatkan petinggi-petinggi negara, seperti keserakahan, dendam, nafsu kemaruk harta, perilaku tidak adil melalui metafora dan metonimi superioritas, ketamakan, dan eksistensi.

\section{PENUTUP}

Novel Menyusu Celeng 2019 merupakan novel yang mengambil isu politik dan kemiskinan sebagai pokok permasalahan yang utama. Berdasarkan hasil analisis tentang ketidaksadaran pengarang yang meliputi kondensasi, pengalihan, dan simbolisasi dalam novel Menyusu Celeng 2019, dapat disimpulkan bahwa novel Menyusu Celeng 2019 merupakan wadah bagi Sindhunata untuk menyuarakan kritik pada pemerintahan yang diliputi keserakahan, korupsi, dengki, dan ketidakadilan. Perspektif Sindhunata dalam memandang kesederhanaan atau kemiskinan secara tidak sadar dituliskan oleh Sindhunata melalui lukisan pada novel dan penggambaran tokoh pelukis sebagai sosok yang bangkit dari keterpurukan. Hal lain yang ingin disampaikan Sindhunata ialah hasratnya dalam kebudayaan yang memang sudah dikenalnya sejak kecil yang hidup dalam lingkungan yang kental dengan kebudayaan.

\section{DAFTAR PUSTAKA}

Bertens, K. (2006). Psikoanalisis Sigmund Freud. Jakarta: PT Gramedia Pustaka Utama.

Budiantoro dan Mardianto, W. (2016). Aplikasi Teori Psikologi Sastra. Purwokerto. Penerbit Kaldera.

Endraswara, S. (2008). Metodologi Penelitian Sastra: Teori, Langkah, dan Penerapannya. Yogyakarta: MedPress.

Himawan, F. U. https://mediaindonesia.com/read/detail/229293-waspadaceleng-bergentayangan. Diakses pada 23 April 2020 pukul 16.54 WIB.

Milner, M. (1992). Max Milner, Freud dan Interpretasi Sastra. Terjemahan oleh Apsanti Ds, Sri Widaningsih, dan Laksmi. Jakarta: Intermasa.

Minderop, A. (2016). Psikologi Sastra. Jakarta: Yayasan Pustaka Obor Indonesia.

Moleong, L. J. (2012). Metodologi Penelitian Kualitatif. Bandung: PT Remaja Rosdakarya.

Ratna, N. K. (2004). Teori, Metode, dan Teknik Penelitian Sastra. Yogyakarta: Pustaka Pelajar

Sindhunata. (2019). Menyusu Celeng. Jakarta: PT Gramedia Pustaka Utama.

Supriyanto, D. https://trenzindonesia.com/2020/01/12/sindhunata-bukankita/. Diakses pada 23 Juni 2020 pukul 10.20 WIB.

Susanto, D. (2012). Pengantar Teori Sastra. Yogyakarta: Caps Media. 
Nuansa Indonesia

Volume 22(2), November 2020, https://jurnal.uns.ac.id/ni

p-ISSN: 0853-6075

Wiyatmi. (2011). Psikologi Sastra: Teori dan Aplikasinya. Yogyakarta: Kanwa Publisher. 